DOI: $10.15421 / 4219038$

UDC 539.3

\author{
S. A. Morhun, PhD (Tech.)
}

\title{
GAS TURBINE ENGINES IMPELLERS FORCED VIBRATION AND STRESS-STRAIN STATE INVESTIGATION
}

The method of the gas turbine engine impeller forced vibration and stress-strain state parameters calculation is given. Using the finite element method, a refined mathematical model was developed for the several types of impellers most widespread in the practice of gas turbine engines building. The developed mathematical model takes into consideration the impeller blades geometric parameters and the construction of blades connectors. The results of its forced vibration frequencies calculation, caused by the influence of non-stationary gas flow are given for different types of the blades connectors. The dependencies of the impeller blades stress-strain state from the value its feather geometric parameters have been studied too.

Keywords: gas turbine, impeller, forced vibration, vibration frequency, stress-strain state, blades connectors.

Introduction. The idea of the turbine engines life increasing is of practical interest and is an urgent problem for applied mechanics. The rapid pace of turbine engines development is accompanied by a constant increase in the intensity of the processes occurring in them with a general increase in the requirements for their strength and reliability. Therefore, one of the basic tasks for the turbine rotor development is to calculate its vibration modes and frequencies. Then it will be possible to find out the turbine rotor stressstrain state.

On the one hand this idea has been postulated for many times before. But on the other hand it is still actual. The matter is that the blades are one of the most crucial elements of a turbine due to extremely hard working conditions and their constructional heterogeneity, caused by a system of cooling channels in their cavities. So one of the most important moments of the turbines and even compressors design is not only the finding of the blades natural frequencies and modes, but also a more comprehensive study of vibration processes in the rotor, caused by an influence of a nonstationary gas flow. Such research is also impossible without taking into consideration the processes of internal and structural damping in the blades feather joints that are called "damping links" or bandages. For all its complexity described problem requires the constant expansion and deepening of theoretical ideas about the dynamic phenomena associated with the working process of gas turbine engine. It should be mentioned that the experimental studies of the aforementioned problem are extremely hard 
or even impossible due to the high temperatures of gas flow that influences the turbine rotor.

Due to the high cost of modern turbines and especially works on their fine-tuning, the methods of their rotors vibration characteristics determining are of great importance even at the design stage. Therefore, a comprehensive study of the vibration of the blade apparatus, taking into account the specifics of its elements and their interaction, is a serious scientific and practical problem, and, despite intensive research in this area [1 - 3], remains a number of unresolved aspects.

Thus, the use of simplified design schemes based on the application of the core theory [1] does not allow to identify the important features of the system, such as the influence of damping on the blades vibration frequencies. Within the framework of this theory, the blades are considered as twisted, inextensible and rigidly fixed in the disk rods of variable crosssection, making common-mode oscillations in one of the main bending planes. In [4], forced vibrations of the turbine engine blades are investigated using the method of initial parameters; however, it does not indicate a method for the intensity of the disturbed gas dynamic forces calculating. In [3], asymptotic methods of nonlinear dynamics are used to solve the differential equations of impeller forced vibration, but the damping in the system is not taken into account. In works $[2,5]$, this problem is solved using the finite element method, but in [5] the damping is not taken into account, and in [2], when constructing a finite-element mathematical model of a blade, finite elements like "tetrahedron" are used, which do not allow take into consideration the blade constructional heterogeneity. The technique of compressors and turbines working blades free vibration frequencies experimental study is given in [6, 7], however, the experimental data are less reliable, since in the course of the experiment there are always unavoidable systemic errors of the experimental setup itself and measuring equipment.

Purpose of the study. The development of a set of measures for the gas turbines reliability increase is not feasible without a detailed study of vibration processes occurring in such critical details as turbine blades, influenced by non-stationary gas-dynamic forces of high temperature. However, as follows from the above analysis of recent research on this topic, some important aspects remain insufficiently illuminated, therefore, it is necessary to develop a refined mathematical model of the blades forced vibration and their stress-strain state. It is also necessary to take into consideration the significant constructional heterogeneity of the impellers cooled blades.

Therefore, the aim of this work is to develop a refined mathematical model of the turbine cooled blades with bandages system (impeller) stressstrain state calculation, based on the usage of finite elements method. Full description of the finite elements that are suitable for the impeller correct modeling is given in the works [8 - 10].

Study. The task of the gas turbine impeller stress-strain state determining is given. It is also assumed that the considered system of solid 
bodies (impeller) has the properties of cyclic symmetry. So it can be interpreted as a set of $h$ subsystems (sections) with the same geometric, inertial and stiffness properties [7]. In this case, $h$ determines the system order of symmetry. So a section of such impeller generally includes a disk sector and a blade set in it with parts of damper links (fig. 1). The section is located in the rectangular right $X Y Z$ coordinate system: $X$ axis coincides with the axis of turbine rotor rotation, $Z$ axis is directed along the impeller radius, and the $Y$ axis is perpendicular to the $Z$ axis.

The finite element model of an impeller blade was built on the basis of superparametric curvilinear finite elements. Each of them consisted of 20 nodes with 5 degrees of freedom in every node. The damper links, connecting the blades in a unity were modeled using a rod finite element. The disk model included 230 first-order hexagonal finite elements with 1254 degrees of freedom totally [9].

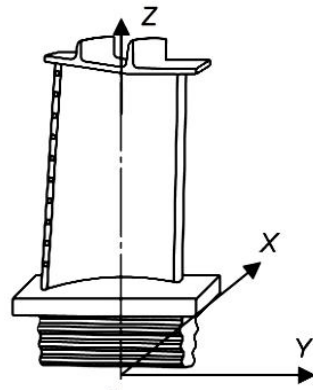

a

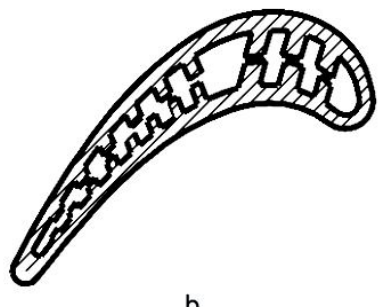

b

Fig. 1 - Turbine blade in the Cartesian coordinate system

a) three-dimensional model of cooling turbine blade;

b) transverse section of the shoulder blade

To study the impeller forced vibration amplitudes and frequencies let's use the Lagrange variation principle.

$$
\frac{\partial L}{\partial q_{i}}-\frac{d}{d t}\left(\frac{\partial L}{\partial \dot{q}_{i}}\right)=0, \quad i=(1, \ldots ., n),
$$

where $L=\Pi-T$ is the Lagrange function; $\Pi$ - potential energy of deformation of the finite elements model; $T$ - kinetic energy of oscillation of the finite elements model; $q_{i}$ - generalized coordinate of $i$-th node; $n$ - total number of the finite elements nodes.

So according to the dependence (1) we need to find the potential and kinetic energy of the impeller. Thus potential energy of the finite element model deformation $(\Pi)$ is described by the dependence (2):

$$
\left.\left.\Pi=\frac{1}{2} \iiint_{V}\{\varepsilon\}^{T} D_{\sigma}\{\varepsilon\} d V=\frac{1}{2} \iiint_{V}[B]^{T} D[B] d V=\frac{1}{2}\left(\{\delta\}^{T}[K]\right\} \delta\right\}\right),
$$


where $\varepsilon$ - vector of the finite element deformation $(\{\varepsilon\}=[B]\{\delta\}) ;[B]-$ matrix of the finite elements gradients $\left([B]=D_{\varepsilon}[N]\right) ;[N]$ - matrix of the finite element shape function; $D_{\varepsilon}-$ differential operator; $\{\delta\}-$ vector of the finite element nodes displacement; $D$ - matrix of elasticity; $[K]-$ matrix of the finite element stiffness; $V$ - finite element volume.

Kinetic energy of the finite element $(T)$ could be found (3):

$$
T=\frac{1}{2} \iiint_{V} \rho\{\delta\}^{T}[B]^{T}[N]^{T}[B][N]\{\delta\} d V=\frac{1}{2}\left(\{\delta\}^{T}[M]\{\delta\}\right),
$$

where $\rho$ - blade material density; $[M]$ - the finite element mass matrix.

$$
[K] a-\Omega^{2}[M] a=\{F\},
$$

where $a$ - the impeller forced vibration amplitudes; $\Omega$ - the impeller forced vibration frequencies; $F$ - the vector of the gas dynamic forces, causing the impeller vibration.

On the base of dependencies $(2,3)$ we form the vector of the finite elements model stresses. It has the form (5):

$$
\{\sigma\}=D\left(\{\varepsilon\}-\left\{\varepsilon_{0}\right\}\right),
$$

where $\varepsilon_{0}$ - vector of the finite element heat deformation $\left(\left\{\varepsilon_{0}\right\}=\left\{\alpha^{T} T^{e} \quad \alpha^{T} T^{e}\right.\right.$ $\left.\left.\begin{array}{llll}\alpha^{T} T^{e} & 0 & 0 & 0\end{array}\right\}^{T}\right) ; \alpha^{T}$ - coefficient of temperature expansion of the material; $T^{e}$ - temperature of the element.

Main results and their analysis. In order to find out the practical suitability of the developed mathematical model, a study was conducted of the gas turbine impeller forced vibration frequencies and its stress-strain state. The studied impeller consists of 65 working blades of variable cross section with damping links. The height of the blade $I=115 \mathrm{~mm}$; the material of the blades - heat-resistant alloy (material density $\rho=8100 \mathrm{~kg} / \mathrm{m}^{3}$, Young's modulus $E=1.79 \times 10^{6} \mathrm{MPa}$, Poisson's ratio $u=0.3$ ). The diameter of the disk $D=375 \mathrm{~mm}$. The exit angle of flow from the nozzle channels $\alpha 1$ was changed from $16^{\circ} 30^{\prime}$ to $18^{\circ} 30^{\prime}$; the exit angle of flow from the impeller $\alpha 2=73^{\circ}$.

Firstly we will study the gas turbine impeller forced vibration amplitudes (Fig. 2).

On the fig. 2 the graphical dependence of the amplitudes of forced oscillations of the considered impeller on the ratio of the pressure drop of the gas flow before and behind the considered turbine stage $\Delta p(\Delta p=p-p 1)$ to the pressure before stage $p(\mathrm{MPa})$ are shown. The graphic data indicate that with an increase in the ratio of pressure drop to flow pressure before the turbine stage under consideration, the amplitude of forced oscillations of the impeller increases. The explanation for this is the increase in deformation of the surfaces of the impeller in contact with the incoming flow. 


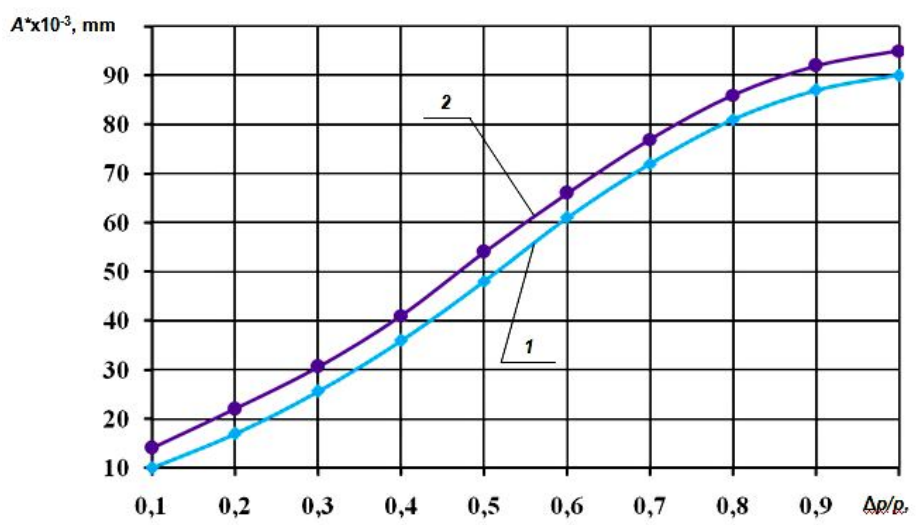

Fig. 2 -The dependence of the impeller forced vibrations amplitudes from the ratio of the pressure drop of the gas flow to the pressure in front of the stage:

1 - an impeller with bandages; 2 - an impeller with damping links

After finding the amplitudes of the impeller forced vibration we have an opportunity to find its forced vibration frequencies according to the dependence (4).

The matter is that the value of the impeller forced vibration frequency is sharply influenced by the form of joints, connecting the separate blades into the impeller. Table 1 shows the impeller forced vibration frequencies depending on its vibration mode (the number of nodal diameters $D_{n}$ ) for the main types of the impeller structures.

Analysis of the calculation results, given in table. 1, indicates that for the same number of nodal diameters, the maximum of forced vibration frequencies occurs in the impeller, the blades of which are connected by means of Z-shaped bandages, and the smallest - when connected by means of two damper links. Explaining this fact is that the impeller, which was bandaged by means of bandages shelves, has the maximum flexural rigidity and, as a result, the highest oscillation frequency. Conversely, the impeller, the blades of which are combined with the help of damper links, has the lowest oscillation frequency, because the potential deformation energy of it is dissipated due to friction that occurs when the damper and the blade contact. In the case of a combined bandage design, in addition to the damper and blade feather contact, there is a slight slippage between the middle of the bandages. This also leads to a decrease in the frequency of the impeller forced vibration, although it increases its rigidity in comparison with impeller, joined by damping connections.

From the point of view of maximally reducing the vibration frequency it is most expedient to use structures with two damper couplings, however, such compounds can only be used in turbines with a low flow temperature. Bandaged impellers should be used in high-loaded gas turbines with highpressure and temperature of the gas flow. Therefore, the combined design of the blade connections of the impeller is optimal. 
Table 1 - Frequencies of the impeller forced vibrations of a blade ring, depending on the design of connections

\begin{tabular}{|c|c|c|}
\hline $\begin{array}{c}\text { Design of } \\
\text { connections }\end{array}$ & $\begin{array}{c}\text { Quantity of nodal diameters, } \\
D_{n}\end{array}$ & $\begin{array}{c}\text { The impeller forced } \\
\text { vibration frequency } \\
\Omega, \mathrm{Hz}\end{array}$ \\
\hline \multirow{2}{*}{$\begin{array}{c}\text { Z-shaped } \\
\text { bandages }\end{array}$} & Form of bandages \\
\cline { 2 - 3 } & 2 & 1205 \\
\hline \multirow{3}{*}{ Arc bandages } & 3 & 1263 \\
\cline { 2 - 3 } & 4 & 1325 \\
\cline { 2 - 3 } & 2 & 1174 \\
\hline \multirow{3}{*}{$\begin{array}{c}|c| \\
\text { One damping link }\end{array}$} & 4 & 1235 \\
\cline { 2 - 3 } & Damping links & 1297 \\
\hline \multirow{2}{*}{$\begin{array}{c}\text { Two damping } \\
\text { links }\end{array}$} & 2 & 1097 \\
\cline { 2 - 3 } & 3 & 1199 \\
\cline { 2 - 3 } & 4 & 1230 \\
\hline \multirow{2}{*}{$\begin{array}{c}\text { Damping link } \\
\text { and bandage }\end{array}$} & 2 & 1063 \\
\cline { 2 - 3 } & 3 & 1155 \\
\cline { 2 - 3 } & 4 & 1194 \\
\hline
\end{tabular}

Now let's take into consideration the influence of the impeller blades geometrical parameters on its stress-strain state (Fig. 3 - Fig.5).

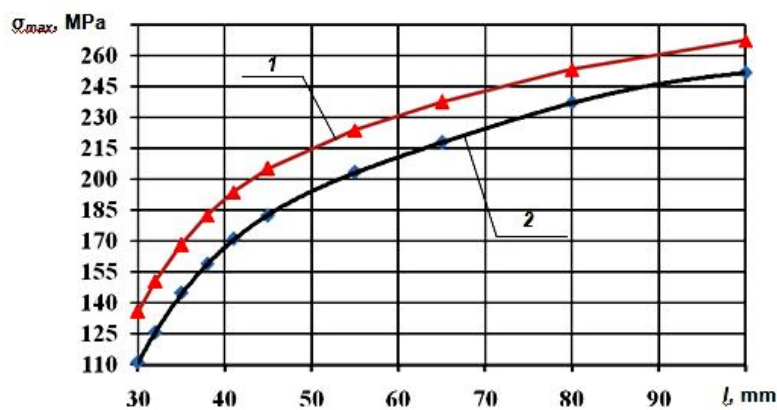

Fig. 3 - The value of maximum dynamic stresses in impeller according to its blades feather length value:

1 - bandaged impeller; 2 - impeller with damper connections

Analysis of the graphical dependencies shown in Fig. 3 - Fig.5, indicates that the level of maximum dynamic stresses in the impeller increases with the increasing of the blades length (Fig. 3). This can be explained by the fact that with an increase in the length of the blade feather, its rigidity decreases and, therefore, the magnitude of the impeller stresses increases too. An increase in such a parameter as a chord (Fig. 4) leads to an increase of the blade cross-sectional area and, as a consequence, to a decrease of impeller 
stresses. An increase in the blade feather twist angle also leads to an increase of impeller stresses, because an increase in the twist of the blade peripheral section leads to a decrease in the rigidity of the whole blade. An increase in the thickness of the blade feather (Fig. 5), on the contrary, leads to a decrease in stresses, because in this case the cross-sectional area of the blade feather increases too.

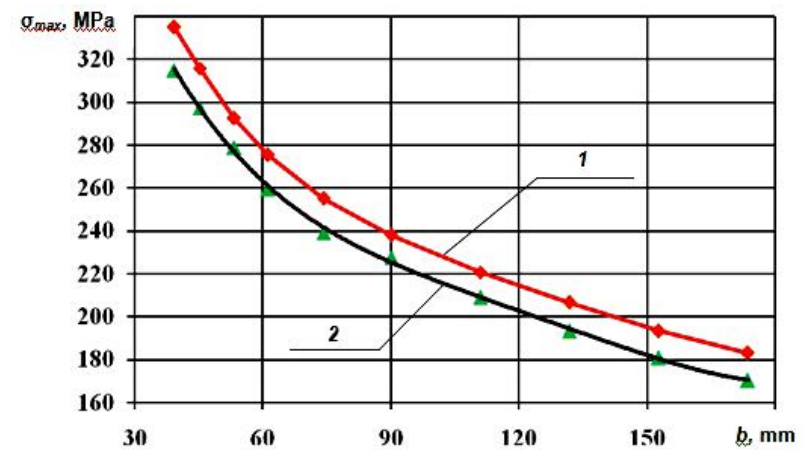

Fig. 4 - The value of maximum dynamic stresses in impeller according to its blades chord value:

1 - bandaged impeller; 2 - impeller with damper connections

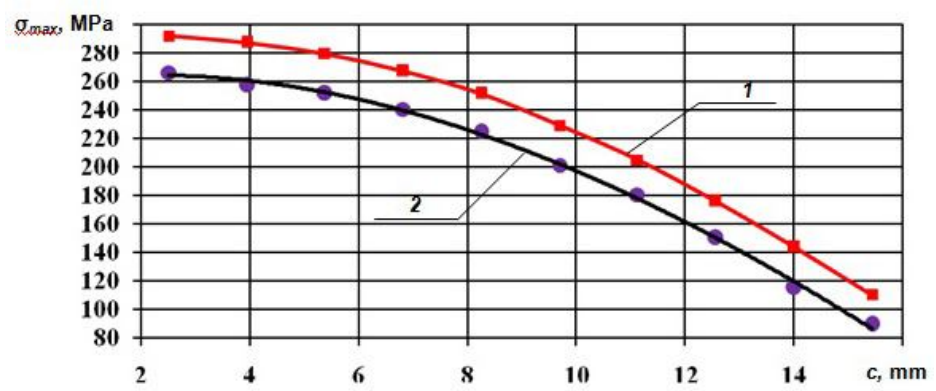

Fig. 5 - The value of maximum dynamic stresses in impeller according to its blades feather thickness value:

1 - bandaged impeller; 2 - impeller with damper connections

Conclusion. Using the finite element method, the problem of the gas turbine engine impeller forced vibration amplitudes, frequencies and stressstrain state calculating has been solved. To solve this problem, a refined mathematical model on the base of FEM has been developed. The main attention has been paid to the impeller blade maximum stresses and the dependencies between them and the blade geometric parameters. On the other hand the influence of the various types of connections, joining the blades into impeller, on its forced vibration frequencies has also been studied. So by the usage of such mathematical model the full account of the impeller design features could be taken into consideration. Analysis of the 
obtained results confirms the adequacy of the developed mathematical model and indicates that the design of an impeller with Z-shaped bandages is much more preferable from the point of view of its vibration reliability. The obtained results, especially given in the table 1 and on the Fig. 3 - Fig. 5, can be used for the further study of the gas turbine impeller stress-strain state as well as for the purpose of the impeller geometry optimization.

\section{REFERENCES}

1. Vorob'ev Ju. S. The turbine engines blade oscillations. Kiev: Naukova dumka, 1988. 224 p. (in Russian).

2. V'yunov S.A., Gusev Yu. I. The aviation gas turbine engines construction and design. Moscow: Mashinostroenie, 1989. 564 p. (in Russian).

3. Kopelev S. Z. The computation and design of the gas turbine engines cooled blades. Moscow: Nauka, 1988. 145 p. (in Russian).

4. Kostjuk A. G. The turbine dynamics and strength. Moscow: MEI, 2009. 264 p. (in Russian).

5. Postnov V. V., Starovoitov S. V., Fomin S. Yu., Basharov R. R. Theoretical and experimental stress-strain analysis of machining gas turbine engine parts made of the high energy structural efficiency alloy. // Journal of Engineering Science and Technology Review. 2014. Vol. 7, Iss. 5. P. 47-50.

6. Sosunov V. A., Chepkin V. M. Teoriya, raschet i proektirovanie aviacionnyh dvigateley $\mathrm{i}$ energeticheskih ustanovok (The theory, calculation and design of the aircraft engines). Moscow: Mosk.energ. in-t., 2003. 677 p.

7. Pykhalov A. A., Milov A. E. Staticheskiy i dinamicheskiy analiz sbornyh rotorov turbomashin (Static and dynamic analysis of the turbine rotors assemblies). Irkutsk: Izd-vo Irkut. tekhn. un-ta, 2007. 194 p. (in Russian).

8. Morgun S. The blades constructions finite element models development // Bulletin of the National Technical University «KhPl». Ser.: New Solutions in Modern Technologies. 2016. Iss. 42 (1214). P. 86-91. DOI: 10.20998/2413-4295.2016.42.14

9. Morhun S. The turbine engine blades stress-strain state under the vibration load. Technology transfer: fundamental principles and innovative technical solutions. 2017, No 1 , P. 48-50. DOI: http://dx.doi.org/10.21303/2585-6847.2017.00478

10. Morhun $\mathbf{S}$. The influence of the blade feather constructional inhomogeneity on the turbine cooling blades stress-strain state // Eastern-European Journal of Enterprise Technologies. Ser.: Applied Mechanics. 2018. Iss. $2 / 7$ (92). P. 11-17. DOI: 10.15587/17294061.2018.125937.

УДК 539.3

С. А. Моргун, канд. техн. наук

\section{ИССЛЕДОВАНИЕ ВЫНУЖДЕННЫХ КОЛЕБАНИЙ И НАПРЯЖЕННО-ДЕФОРМИРОВАННОГО СОСТОЯНИЯ ЛОПАТОЧНОГО ВЕНЦА ГАЗОВОЙ ТУРБИНЫ}

Представлена методика определения параметров вынужденных колебаний и напряженно-деформированного состояния лопаточного венца газовой турбины. На основе метода конечных элементов разработана уточненная математическая модель, использованная для исследования наиболее распространенных в практике турбостроения лопаточных венцов. Данная математическая модель учитывает геометрические параметры лопаток, а также 
конструкцию связей между ними. Результаты определения частот вынужденных колебаний лопаточного венца, вызванные воздействием нестационарного газового потока, приведены для разных типов связей лопаток в венце. Исследовано напряженно-деформированное состояние лопаток венца в зависимости от геометрических характеристик их пера.

Ключевые слова: газовая турбина, лопаточный венец, вынужденные колебания, частота колебаний, напряженно-деформированное состояние, межлопаточные связи.

УДК 539.3

С. О. Моргун, канд. техн. наук

\title{
ДОСЛІДЖЕННЯ ВИМУШЕНИХ КОЛИВАНЬ ТА НАПРУЖЕНО-ДЕФОРМОВАНОГО СТАНУ ЛОПАТКОВОГО ВІНЦЯ ГАЗОВОЇ ТУРБІНИ
}

\begin{abstract}
Надано методику визначення параметрів вимушених коливань та напружено-деформованого стану лопаткового вінця газової турбіни. 3 використанням методу скінченних елементів розроблена уточнена математична модель, яку застосовано для дослідження найбільш розповсюджених в практиці турбобудування лопаткових вінців. Дана математична модель враховує геометричні параметри лопаток, а також конструкцію міжлопаткових зв'язків. Результати визначення частот вимушених коливань лопаткового вінця, викликаних дією нестаціонарного газового потоку, наведено для різних типів міжлопаткових зв'язків. Досліджено напруженодеформований стан лопаток вінця В залежності від геометричних характеристик їх пера.

Ключові слова: газова турбіна, лопатковий вінець, вимушені коливання, частота коливань, напружено-дефрормований стан, міжлопаткові зв'язки.
\end{abstract}

Національний університет

суднобудівництва ім. адмірала Макарова

Миколаїв, Україна

Надійшла до редколегії 11.03.2019 